\title{
Managing Construction Risks of the Toll Road Project in Indonesia
}

\author{
Ari Sandhyavitri", Indrayadi Talha ${ }^{\#}$, Manyuk Fauzi ${ }^{\#}$, Sigit Sutikno ${ }^{\#}$ \\ \# Civil Engineering Department, Engineering Faculty, Universitas Riau, Jl. Soebrantas, Pekanbaru, 28293, Indonesia \\ E-mail: ari.sandhyavitri@lecturer.unri.ac.id,indrapastibisa@gmail.com,graperia@yahoo.com,ssutiknyo@yahoo.com
}

\begin{abstract}
Constructing a toll road project required relatively high capital outlays and involving complicated activities. The typical of the project is classified as sensitive to risks and uncertainties. Proper risk management during construction lifecycle period may yield substantial certainties in reducing risk costs. The risk costs were calculated using stochastic analyses. The results showed that there were 7 main activities which were considered as the riskiest ones, and in need to manage such as; construction of concrete structures, road pavement, ground works, interest during construction (IDC), escalation costs, base and sub-base course aggregate, and land acquisition activities. This study identified that before conducting risk mitigation, there was $90 \%$ probability of the project costs would be at the range of IDR 23.06 Trillion to IDR 23.96 Trillion. After implementing risk mitigation, there was $90 \%$ probability the project cost would decrease at the range of IDR 21.53 Trillion to IDR 22.42 Trillion. Risk Management may reduce project risk costs systematically.
\end{abstract}

Keywords — risk management; toll road; project life cycle; probabilities; costs

\section{INTRODUCTION}

Failure in identification and managing project risks may fail achieving project objectives [1], [2], [3]. The development of a feasibility study for constructing the toll roads connecting Pekanbaru City to Dumai City 135.34 kilometres was initiated by the Government of Riau Province, Indonesia in 2004 and has been listed in the Presidential Decree No. 100/2014 concerning the Acceleration of Highway Development Programs in Sumatra Island, Indonesia [4], [5].

The government assigns to the state-owned company, PT. Hutama Karya (Persero) in providing project financing, planning, design, construction, operation and maintenance of this toll road. It was planned that the construction of this toll road will be divided into three main sections; Section I. Pekanbaru - Kandis, Section II Kandis - Duri, and Section III Duri - Dumai (Fig. 1).

It was calculated that the "initial cost estimate" for the construction of this toll road was IDR 21.78 trillion (based on 2015 data). It is identified that the largest portions of the toll cost expenditures were as follow; Pavement costs (rigid and flexible pavements) $13.96 \%$, concrete structures (for constructing of bridges. Fly-overs and pillars) $19.71 \%$, Earthwork (cut and fill) $11.33 \%$, and Interest during Construction (IDC) $11.25 \%$ (Fig. 2), totalling $56.25 \%$ of the project costs [6], [7], [8].

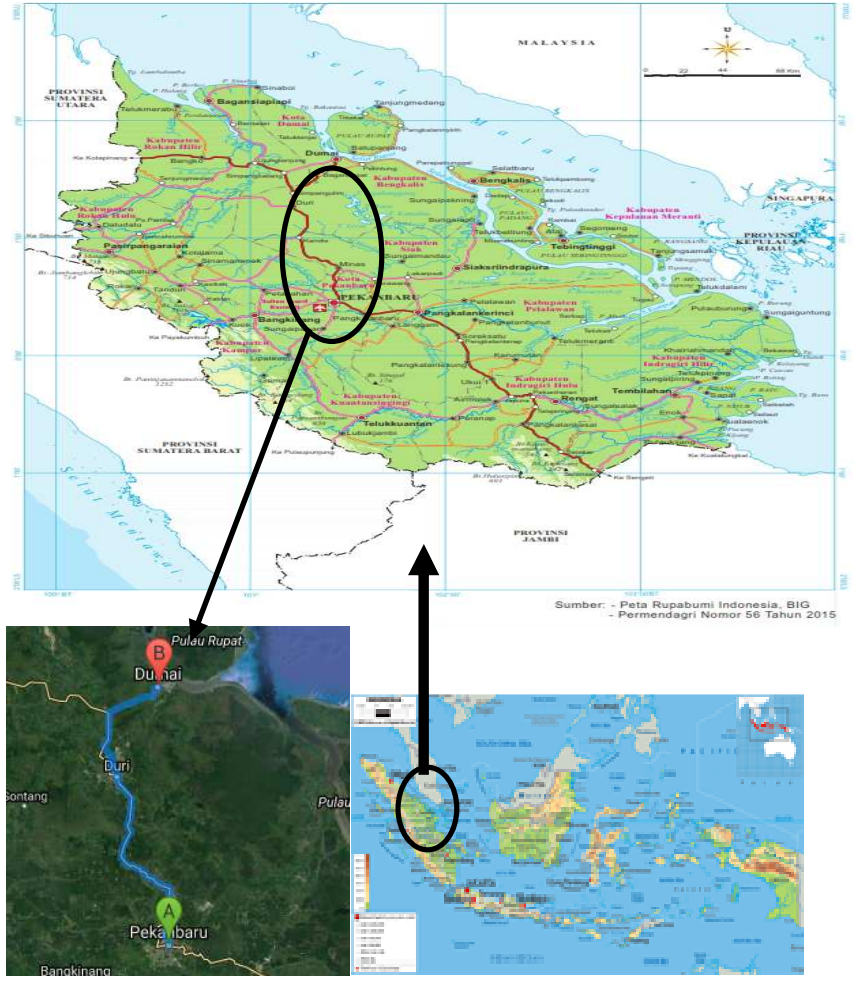

Fig.1 Toll road of Pekanbaru - Dumai Location [6] 


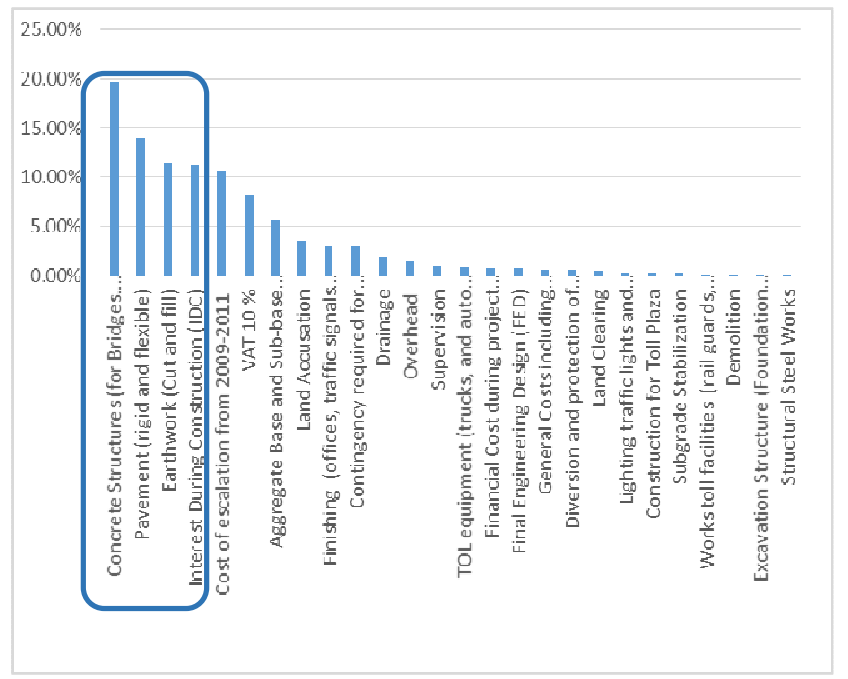

Fig. 2. Aggregation of the project costs

It was acknowledged that there were various publications related to the risk management (RM) of the toll road development projects around the world, such as in Palestine Argentina, Indonesia, Saudi Arabia, and Canada. These studies identified 45 significant risks affecting delays of the road construction projects in West Bank Palestine, 2013 [9], and the importance of strong government supports in the development of toll road in Argentina, tariffs collection, investment policy, and optimization of risk allocation between road users and the project concessionaire, 2002 [10]. During the pre-construction phase the development of toll project in Indonesia has identified five main risks affecting to project success encompassing; project permissions, feasibility study, detailed design, land acquisition and investment, 2015 [11]. Again a road construction research study conducted in Saudi Arabia identified 41 main factors causing cost overrun, 2013 [12].

This paper is concerned in the mitigation of risk costs in the construction for the toll project lifecycle, PekanbaruDumai, Indonesia.

These paper objectives are to; identify the construction risks of the toll road project-lifecycle (encompassing preconstruction stage, construction, and project close up stage), calculating risk factors and risk categories, analyses the risk costs based on the stochastic methods, and mitigating the significant identified risks.

\section{MATERIAL AND METHOD}

Risk Management (RM) has also been applied in various projects including petroleum industry, infrastructure, and toll road [13], [14], [3], [15]. Risks and uncertainties cause time delay, cost overrun, and poor quality results [16], [14]. The $\mathrm{RM}$ is a systematic method for identification, analysing and mitigating potential project risks in achieving the project objectives and targets in terms of time, money, and quality [14], [17]. RM can be conducted by three major steps: identification of risk, risk assessment, and risk mitigation/control [18], [19], [20]. Risk analysis methods, namely sensitivity analysis (using Tornado diagram) and, Monte Carlo simulation was then applied in the analyses [21], [22], [23].

\section{A. Project Lifecycle}

Project lifecycle during the construction phase is a series of project stages, starting from the development of project concept, feasibility study, project design, project procurement, project construction, and project closing stages [16], [24]. The terminology of the project lifecycle in this paper was simplified into three main stages such as; preconstruction phase, construction phase, and project close-up.

- Pre-construction Phase may involve the following stages; concept development (project definition). Planning stages (design and engineering), land acquisition, and project procurement stages.

- Implementation phase may include project finance, project construction, equipment procurement, and project development stages.

- Project close-out. This phase terminated the project implementation phase, and handed over the project to the project owner.

The management of risks in the toll road project lifecycle was drawn as follow (Fig. 3).

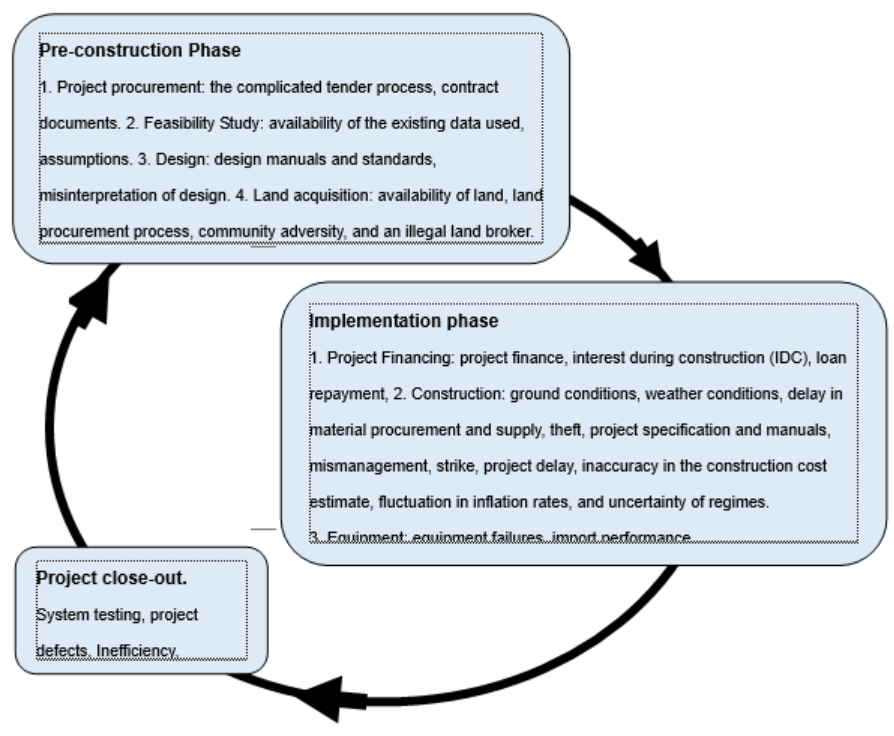

Fig. 3. Risk Element Based on Project Phases

\section{B. Field Survey}

A field survey was conducted to identify the potential risks associated with the project construction phase. This survey distributed questioners to a toll regulator in Indonesia (such as Toll Road Regulatory Agency, BPJT), and 4 major toll road operators, such as PT. Jasa Marga, PT. Marga Sarana Jabar, PT. Trans Lingkar KJ, dan PT. Bintaro Serpong Damai. The questioner was consisted three major variables, for example; (i) risks associated with project preparation (including final engineering design, land acquisition, and contracts), (ii) project construction activities (earth-works, pavements, and concrete structures), and (iii) cost escalation during 2009-2015.

This survey then calculated the values of risk probability and risk impacts of each single project activity in order to yield risk factors (RF) and risk category [25], [26]. 


\section{Risk Factors}

Risk factors (RF) were calculated by multiplication of the probability of the risk likelihood (frequency) with the risk impacts (consequences). This is calculated based on the following equation [25].

$$
\mathrm{RF}=\mathrm{L}+\mathrm{I}-(\mathrm{L} \times \mathrm{I})
$$

With:

$$
\begin{array}{ll}
\mathrm{RF} & =\text { Risk factors } \\
\mathrm{L} & =\text { Probability of risk likelihoods (Scale } 1 \text { to } 5) \\
\mathrm{I} & =\text { Risk impacts (Scale } 1 \text { to } 5 \text { ) }
\end{array}
$$

The scale assessment for the risk likelihood (L) of the project activities is defined in the form of Likert Scale 1 to 5, such as very rare to very frequent level [25], [27]. This can be seen in Table 1.

TABLE I

LIKELIHOOD (FREQUENCY)

\begin{tabular}{|l|l|l|}
\hline Frequency & level of probability (L) & Scale \\
\hline Very Frequent & $80 \% \leq \mathrm{P}<100 \%$ & 5 \\
\hline Frequent & $60 \% \leq \mathrm{P}<80 \%$ & 4 \\
\hline Often & $40 \% \leq \mathrm{P}<60 \%$ & 3 \\
\hline Rare & $20 \% \leq \mathrm{P}<40 \%$ & 2 \\
\hline Very Rare & $0 \% \leq \mathrm{P}<20 \%$ & 1 \\
\hline
\end{tabular}

The magnitudes of the risk impact (I) were measured in the following Table 2 . There are 5 scales, starting from no impacts (scale 1) to catastrophic impacts (scale 5) [25], [27].

TABLE II

IMPACTS (CONSEQUENCES)

\begin{tabular}{|l|c|c|}
\hline Frequency & level of consequences (I) & Scale \\
\hline Catastrophic & $\mathrm{P} \geq 60 \%$ & 5 \\
\hline Very serious & $45 \% \leq \mathrm{P}<60 \%$ & 4 \\
\hline Serious & $15 \% \leq \mathrm{P}<45 \%$ & 3 \\
\hline Not serious & $5 \% \leq \mathrm{P}<15 \%$ & 2 \\
\hline No impacts & $0 \% \leq \mathrm{P}<5 \%$ & 1 \\
\hline
\end{tabular}

\section{Risk Category}

Risk category qualitatively identifies and addresses the most critical risk into 3 levels, such as high risks, medium risks, and low risks [25]. This category also recommends appropriate respond to manage the risks systematically (Table 3).

TABLE III

RISK CATEGORY

\begin{tabular}{|l|c|c|l|}
\hline No & $\begin{array}{c}\text { Risk } \\
\text { Factor } \\
\text { (FR) }\end{array}$ & $\begin{array}{c}\text { Categor } \\
\mathbf{y}\end{array}$ & \multicolumn{1}{|c|}{ Risk Responses } \\
\hline 1 & $>0.7$ & High risk & $\begin{array}{l}\text { Need special attentions in the } \\
\text { forms of risk mitigation and } \\
\text { control procedures reducing the } \\
\text { identified risks in systematic and } \\
\text { comprehensive steps. }\end{array}$ \\
\hline 2 & $0.4-0.7$ & Medium risk & $\begin{array}{l}\text { Need some attentions and } \\
\text { corrections to reduce risk } \\
\text { category to the lower level. }\end{array}$ \\
\hline 3 & $<0.4$ & Low risk & $\begin{array}{l}\text { It is necessary to conduct some } \\
\text { corrections as long as there are } \\
\text { adequate resources. }\end{array}$ \\
\hline
\end{tabular}

For example, based on the initial surveyed data, it was identified that the land acquisition activities yields the probability of risk likelihood was at the level of 0,643 , and the risk impact was at the level of 0,230 . Hence risk factors $(\mathrm{RF})=0.643+0.230-(0.643 \times 0.230)=0.725$. Based on Table 3 , this land acquisition activity is categorized as high risk activity, which needs a special attention and mitigation [25]. Based on the historical data of the toll road development projects in Indonesia (1973-2015), the land acquisition process has been undoubtedly classified as a complicated process and required a lot of efforts to be settled. The land owners for this toll project were currently occupied by the local communities and the private sectors in the form of palm oil plantation areas, settlement, and agricultural areas. Hence, the land compensation process is adjusted to the Indonesia taxable value rate (NJOP).

\section{RESUlTS AND DISCUSSION}

The results of the risk factors were divided into three phases encompassed; pre-construction phase, construction phase, and project close up. This paper identified 2 significant activities during preconstruction phases, such as land acquisition process, and development of final engineering design (FED). The remaining 24 activities were divided into 2 phases; (i) project construction, and (ii) project close up phase. Total activities were 26 activities (Attachment 1 Table 5).

\section{A. Stochastic analyses}

A range of uncertainties or risky variables is commonly described as a stochastic, which is expressed in the form of probability distribution diagrams. These probability distributions were drawn in the range of minimum to maximum values and the likelihood of occurrence of each single value. Commonly the stochastic is presented as a probability density function (PDF) and cumulative density function (CDF) [23], [26].

\section{B. Risk Assessment Based on Scenario 1 (Before risk mitigation or what it is scenario)}

The PDF for this toll road case study is defined in three following values; minimum value, most likely and maximum one [26]. This PDF was applied in the overall project activities as input data for both scenarios; scenario 1 (analyses before risk mitigation), and scenario 2 (after risk mitigation).

For example, based on the detailed field survey data, it was identified that the probability occurrences of the risks for land acquisition activity (Scenario 1) were identified = 0.322 , and the impact was 0.115 . The risk cost $(\mathrm{CR})$ is defined as follow [25];

$\mathrm{CR}=\mathrm{C} \times \mathrm{P} \times \mathrm{I}$

With;

$\mathrm{C}=$ Cost Components

$\mathrm{P}=$ Probabilities

I = Impacts.

Hence, the risk costs for land acquisition (in IDR 000) $=$ $780,575 \times 0.643 \times 0.230=115,439$ (Appendix 1. Table 5). 
The risk costs for land acquisition activity was distributed using a PERT (Program Evaluation and Review Technique) distribution, which consists of 3 values such as; minimum cost, most likely, and maximum cost [28]. This PERT is almost similar to a Triangular distribution, which consists of three parameters, hence this can be pragmatically used and the parameters results are expressed in a skewed distribution. Consequently, the use of the PERT distribution will produce a smooth shape of the curve places according to the direction of skew.

As the PERT risk distribution contains three values such as; minimum, most likely, and maximum, then an average risk $(\mu)$ can be calculated as.

$$
\mu \equiv \frac{\min +4 \cdot \operatorname{m} . \text { likely }+\max }{6}
$$

Then, the range of values is in between $\alpha 1$ and $\alpha 2$.

$$
\alpha_{1} \equiv 6\left[\frac{\mu-\min }{\max -\min }\right], \quad \alpha_{2} \equiv 6\left[\frac{\max -\mu}{\max -\min }\right]
$$

Probability distribution function, PDF or $(\mathrm{fx})=$

$$
f(x)=\frac{(x-\min )^{\alpha_{1}-1}(\max -x)^{\alpha_{2}-1}}{B\left(\alpha_{1}, \alpha_{2}\right)(\max -\min )^{\alpha_{1}+\alpha_{2-1}}}
$$

and Cumulative distribution function, $\mathrm{CDF}$ or $(\mathrm{Fx})=$

$$
F(x)=\frac{B_{z}\left(\alpha_{1}, \alpha_{2}\right)}{B\left(\alpha_{1}, \alpha_{2}\right)} \equiv I_{z}\left(\alpha_{1}, \alpha_{2}\right)
$$

With:

$$
\mathrm{z} \equiv \frac{\mathrm{x}-\min }{\max -\min }
$$

- $\mathrm{B}$ is Beta function, and $\mathrm{Bz}$ is incomplete Beta function

- Min cost is a continuous boundary of minimum < maximum,

- Most likely is a continuous cost with minimum < most likely $<$ maximum,

- Max is continuous boundary parameter.

Based on the scenario 1, it is identified that the distribution land acquisition (in IDR billion) was as follow; minimum $=780.58$, most likely $=838.29$, and maximum $=$ 896.01. The minimum cost of land acquisition was obtained from the existing cost estimate of the toll development project Pekanbaru - Dumai [6]. The maximum risk costs were obtained from the land acquisition cost + the risks costs, and the most likely costs of the land acquisition were obtained from $1 / 2 \times$ (the minimum costs + the maximum ones).

Based on the risk analyses, it is identified that there is a $90 \%$ of probability of land acquisition costs in between (in IDR billion) 802.40 to 874.20 (Fig. 4).

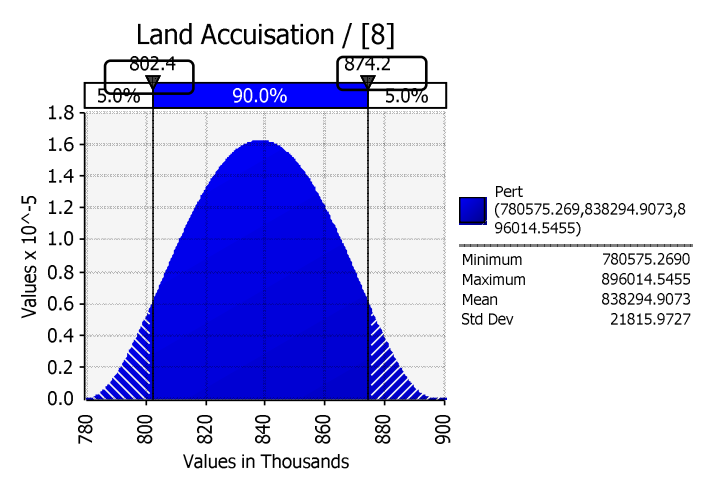

Fig. 4. PDF of land acquisition $90 \%$ in between IDR 802.40 billion to IDR 874.20 billion.

The range of minimum risks, most likely, and maximum of the 26 toll road main activities were presented in Appendix 1 Table 5.

A plot of cumulative distribution values was commonly drawn as a smooth curve cumulative distribution (Fig. 4).

The CDF is presented in the form of a set of probability frequency of occurrence for a defined cost value (Fig. 4 and 5). The CDF commonly as a continuous random variable $X$ with input risk data in the form of a unit area.

\section{Qualitative Risk Analyses}

Based on the risk assessment analyses which was presented in the form of CDF curve, it was identified that there is a $90 \%$ probability of the total project cost will be at the range of IDR 23.06 Trillion to IDR 23,96 Trillion (Fig. $6)$. The values in the Fig. 6 is considered higher than those initial total project costs of IDR 21.78 Trillion (Appendix 1. Table 5).

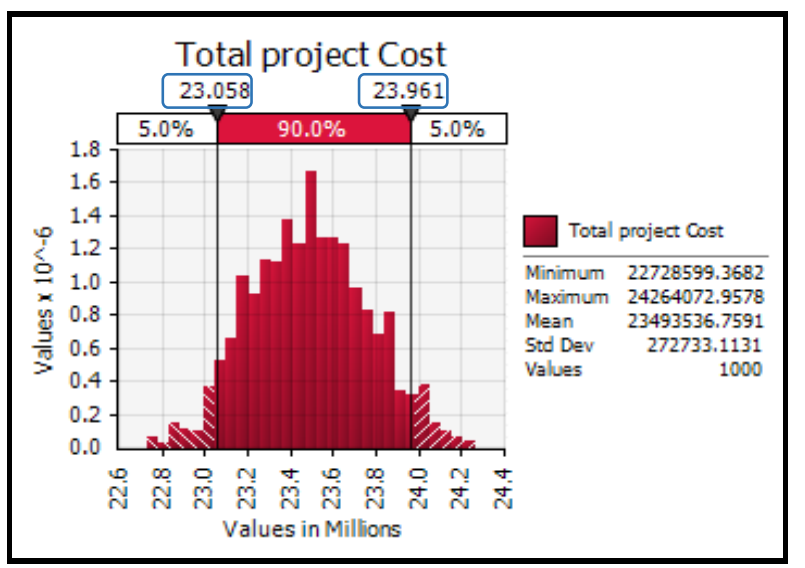

Fig. 5. PDF Curves before risk mitigation with the minimum and maximum values ( IDR 23.06 Trillion to IDR 23,96 Trillion)

It was considered that there were various risks inherent in this toll project have not been mitigated yet (in this scenario $1)$. Then, the overall risks in this project were simulated in the form of cumulative distribution diagram, CDF (Fig. 6). 


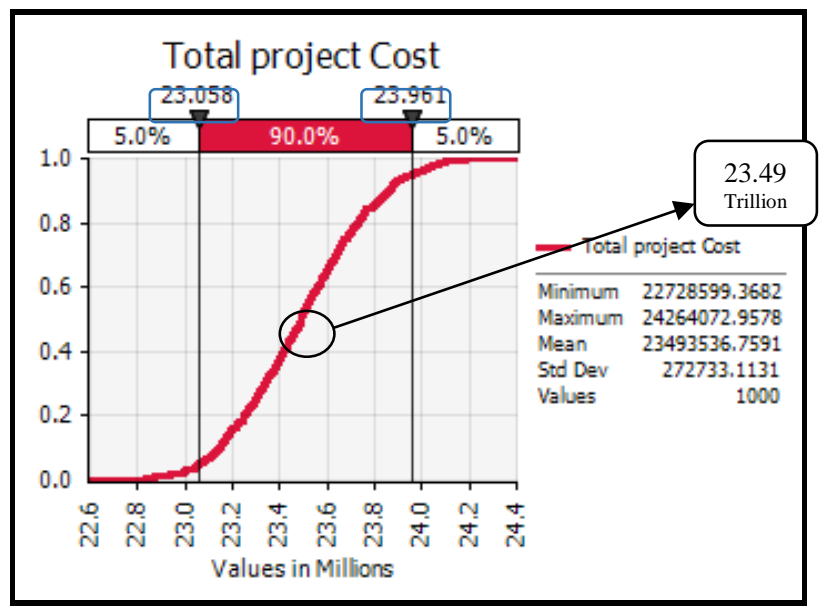

Fig. 6. CDF Curves before risk mitigation with the minimum and maximum values (IDR 23.06 Trillion to IDR 23,96 Trillion)

Based on this quantitative risk assessment, the CDF Fig. 6 shows that there is a $50 \%$ probability of the project cost may reach IDR 23.49 Trillion.

Risk Mitigation Procedure. Not all of risks in the project activities within this toll road will be managed, only 7 the most sensitive activities out of 26 main activities would have been mitigated. This was based on the Pareto principle or $20 / 80$ princisple [29]. In general, this principle stated that $80 \%$ of project impacts caused by $20 \%$ of events Thus $20 \%$ x 26 activities $=5.2$ activities (in this paper considered 7 activities) affected to $80 \%$ of the project costs and a need to mitigate. These 7 activities were obtained from the following Tornado diagram (Fig. 7). This torpedo diagram is used in this paper to display sensitivity or magnitude of those uncertainty variables input $\mathrm{x}$ on the quantity of coefficient value $y$ in a horizontal bar chart. For example, the change in the concrete structure cost is considered sensitive and significant to affect the change of the overall toll project cost (with an-80\% determination coefficient).

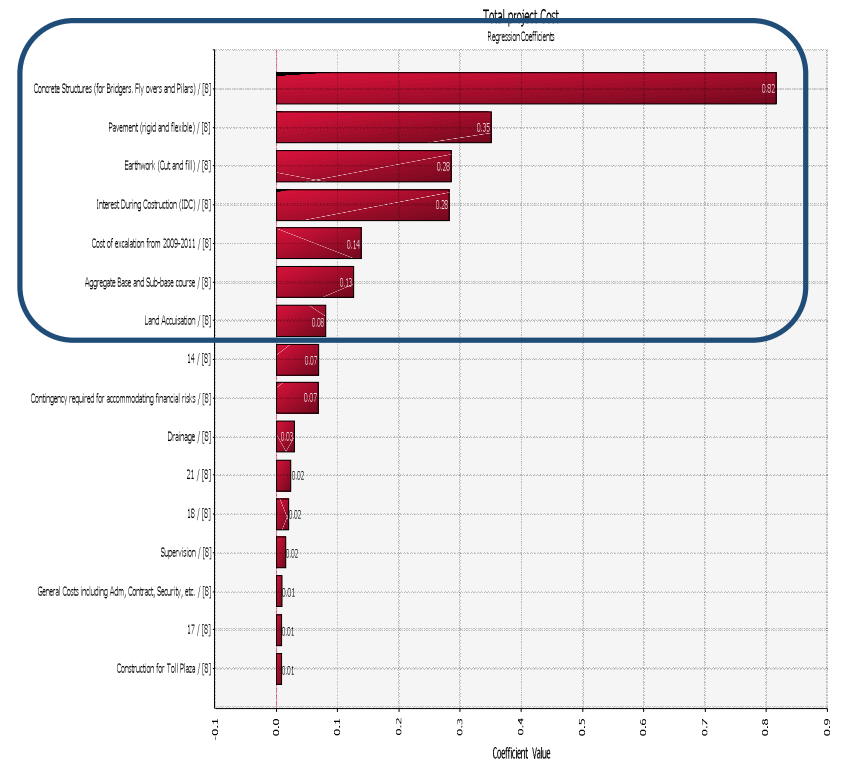

Fig. 7. Tornado diagram of the toll road project costs.

The tornado diagram shows the range of sensitive activities to the project costs. The more sensitive the activities to the change of project costs, the higher their coefficient. Based on Fig. 7, there are 7 the most sensitive activities affected to the total project costs as the following order; concrete structure (determination coefficient 80\%), pavement structures (35\%), earth-works (28\%), interest during construction (IDC) (28\%), the cost of escalation $(14 \%)$, aggregate costs (13\%), and land acquisition (8\%).

1. Concrete structures activities (for constructing bridges, and fly-overs).

The dominant risks of the concrete structure activates are mitigated qualitatively by ensuring continuity for supplying a large amount of concrete materials on time, complying specification standards, within available budgets. It is inevitable that the production of concrete materials in Pekanbaru and Dumai are fluctuating, hence there is a need to maintain stability in the material production rates and establish dedicated concrete mixing plants (CMPs) for this project in order to reduce the risk. Reducing equipment failures are anticipated by conducting a total productive maintenance (TPM) procedures as well as a regular equipment inspection for dump trucks, mobile cement mixer, cement boom trucks, excavators, and loaders. Establishing material supply contracts from a number of robust supplier companies prior to the construction of bridges, and fly-over may reduce these materials shortages. Keeping working progress on schedule may reduce the construction risk from delays [30]. By establishing a proper planning, maintain equipment and labor productivities, punctuality in paying contractors may also reduce the risks.

2. Road pavement construction activities.

The sensitivity analysis showed that the pavement construction activities is classified as the second highest potential risks in this project. Thus there is also a need to maintain the continuity supplying of the flexible pavement materials as well as reducing equipment failure by application of TPM in order to maintain equipment and labor productivity rates. Establishing material supply contract from reputable and entrusted companies may also reduce the risk.

3. Earth work activities.

The dominant risks inherent in the earth work activities are identified in the form of reduction of uncertainty in ground conditions for constructing the sub-grade of the toll road. A comprehensive soil investigation, appropriate soil work methodology, and an adequate number of heavy equipment may reduce the risk during earth work activities. Conducting TPM procedures and regular equipment inspection and checking for excavators, motor graders, dump trucks, and loaders may ensure the stability of working productivity rate, consequently reducing earth work risks.

4. Interest during construction (IDC).

It is acknowledged that different sources of project capital may yield a different IDC risk costs for road developers. The lower the interest rate, the lower the IDC risks will be [30]. Based on the Indonesia Presidential Regulation (PR) No. 56/2011 concerning the Infrastructure Provision through Public-Private Partnership, the government may provide a certain level of incentives (e.g. tax holidays) stimulating foreign investment for development of infrastructure projects in Indonesia, including toll road projects. These incentives may also minimize the IDC risks [31]. Otherwise, Indonesia 
infrastructure guarantee fund (PT. PII) may play crucial roles as a guarantee provider ensuring the safety of the private foreign capital to finance the infrastructure development projects.

5. Cost of escalation

The cost of escalation forecasts the changes in the cost of this toll investment project over a certain period. The cost of escalation may accommodate direct and indirect costs such as; an increase in material costs, labor, equipment costs, electricity, and offices. Hence, forecasting methods of escalation using statistical time series methods may improve the accuracy of the projection, then reducing cost risks. However, the analytical forecasting method commonly only valid for short-term forecasting, not for long-term ones [32].

6. Base course and Sub-base course aggregate for constructing road pavement foundation.

The road pavement foundation consists of the aggregate (for constructing base course and sub-base courses). The aggregate material technical specifications are based on various standards such as ASTM C-33 concerning aggregate classification, SNI 03-2417-1991 concerning aggregate abrasion using Los Angeles machines, and SNI 03-24391991 aggregate and asphalt bondages. Conducting a detail selection procedure for obtaining appropriate aggregates in order to meet the standards may ensure the success of the toll road pavement construction. Implementation of TPM may reduce heavy equipment failure consequently reducing the risk of project delays.

7. Land acquisition activities are also classified as a high risk activity in this project.

This land acquisition is a typical risk intrinsic in the preparation of toll roads development projects [25]. In general, the land acquisition problems arise because of there is a discrepancy between land prices offered by the Government with the market price offered by the land owners. Fortunately, the Indonesia Government has established Law No. 2/2012 concerning the Land Procurement for Development for Public Interest. Thus there is a legal regulation may reduce these land acquisition risks. However, in practice the process of land acquisition has been facing some technical and social barriers. Based on the historical data in Indonesia 1986-2015, most of the land acquisition process for construction of toll roads have been solved systematically by the local governments, and land owners.

Risk Assessment Based on Scenario 2 (After Risk Mitigation). After the implementation of risk mitigation procedures, it was assumed that the cost risks which exist in the 7 significant activities were declined. For example, maximum risk costs (in IDR billion) of land acquisition declines $50 \%$, $(1 / 2 \times 115.44=57.72)$. Hence the distribution of risk costs maximum dropped from 896.01 to (896.02$57.72)=838.30$. The minimum cost is also declined from IDR 780.58 to $(780.58-57.72)=722.86$, and most likely costs declined from 838.30 to become $1 / 2 \times(838.30+722.86)$ $=780.58$ (Appendix 2. Table 6).

After the implementation of the risk mitigation procedures above, the results are presented in Fig. 8.

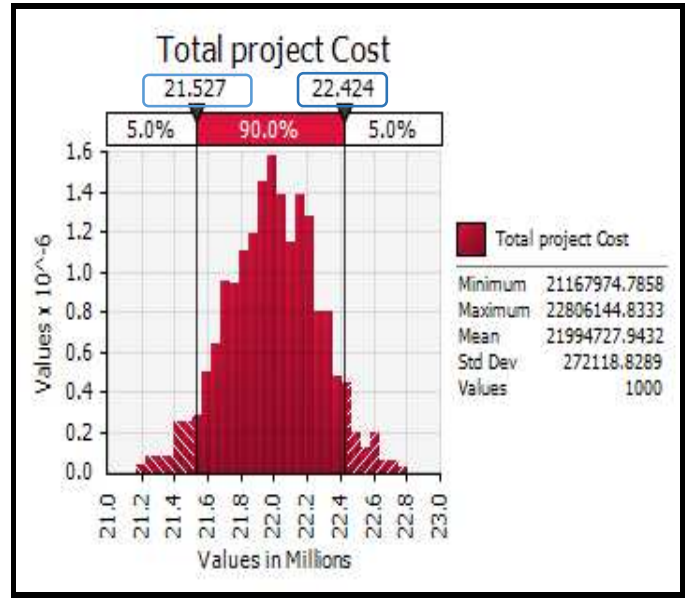

Fig. 8. PDF Curves before risk mitigation with the minimum and maximum values (in IDR Million)

After risk mitigation applied in these activities, it was identified that there is a $90 \%$ probability of the project cost at the range between 21.53 Trillion to IDR 22.42 Trillion (Fig. 9).

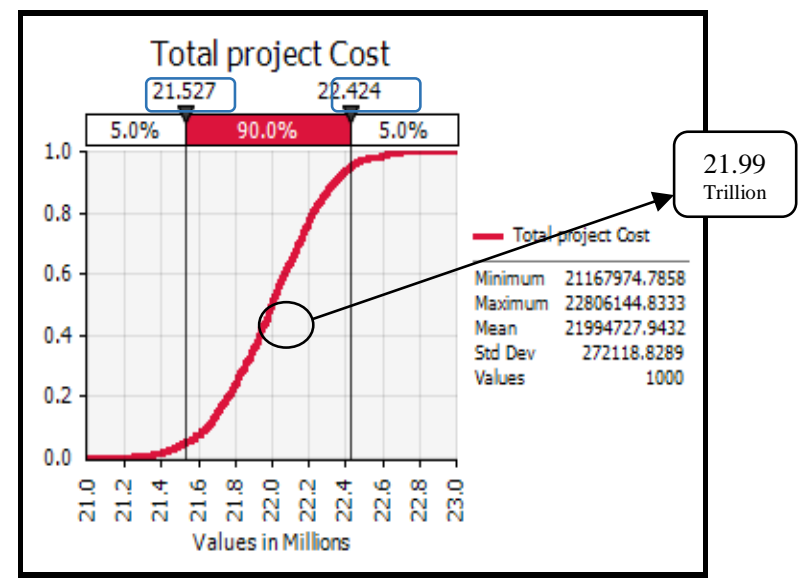

Fig. 9. CDF Curves after risk mitigation with the minimum and maximum values (in IDR Million)

The CDF Fig. 9 shows that there is a $50 \%$ probability of the project cost may reach IDR 21.99 Trillion. The initial project cost of IDR 21.78 Trillion has the probability of $20 \%$ to be applied in this project.

TABLE IV

THE PROBABILITY OF THE PROJECT COSTS

\begin{tabular}{|c|c|c|c|c|}
\hline No & $\begin{array}{l}\text { Cost } \\
\text { Estimate }\end{array}$ & $\begin{array}{l}90 \% \\
\text { probability } \\
\text { cost range }\end{array}$ & $\begin{array}{l}50 \% \\
\text { probabili } \\
\text { ty }\end{array}$ & Description \\
\hline 1 & $\begin{array}{l}\text { Scenario } 1 . \\
\text { Before } \\
\text { Risk } \\
\text { Mitigation }\end{array}$ & $\begin{array}{l}\text { IDR 23.06 } \\
\text { Trillion to IDR } \\
\text { 23.96 Trillion }\end{array}$ & $\begin{array}{l}\text { IDR } \\
23.49 \\
\text { Trillion }\end{array}$ & \multirow{2}{*}{$\begin{array}{l}\text { There is a } \\
\text { discrepancy } \\
\text { between both } \\
\text { scenarios = IDR } \\
1.44 \text { Trillion or } \\
6.7 \% \text {. }\end{array}$} \\
\hline 2 & $\begin{array}{l}\text { Scenario } 2 . \\
\text { After Risk } \\
\text { Mitigation }\end{array}$ & $\begin{array}{l}\text { IDR 21.53 } \\
\text { Trillion to IDR } \\
\mathbf{2 2 . 4 2} \text { Trillion }\end{array}$ & $\begin{array}{l}\text { IDR } \\
21.99 \\
\text { Trillion }\end{array}$ & \\
\hline 3 & $\begin{array}{l}\text { Basic Cost } \\
\text { Estimate }\end{array}$ & \multicolumn{2}{|c|}{$\begin{array}{l}\text { Initial estimate }=\text { IDR } 21.78 \\
\text { Trillion }\end{array}$} & $\begin{array}{l}\text { This is a } 20 \% \\
\text { probability to } \\
\text { achieve the Initial } \\
\text { estimate = IDR } \\
21.78 \text { Trillion. }\end{array}$ \\
\hline
\end{tabular}


Table 5 shows that, after risk mitigation procedure, there is a $50 \%$ probability of reducing cost risk up to IDR 1.44 Trillion $(6.7 \%)$. Thus, risk mitigation procedure may reduce the toll project risks in a systematic procedure. Furthermore, the positive impacts in the implementation of this toll road complete with adequate traffic signs, road markings, safety devices, smart devices (for example Smart Payment Systems) may also reduce traffic congestion, air pollution, and traffic accidents [33], [34], [35]. Hence, by the implementation a systematic risk management procedure and the improvement of road infrastructure and facilities, hence these efforts ultimately may save many life as well as public money [36], [37].

\section{CONCLUSION}

The role of risk mitigation procedure for the toll road Pekanbaru - Dumai, Indonesia is relatively crucial. Before an application of risk mitigation procedure, there is a $50 \%$ probability of the project cost will be IDR 23.47 Trillion. After an application of risk mitigation procedure, there is $50 \%$ probability of the project cost will be IDR 21.99 Trillion. This may reduce the toll road project risks by $6.7 \%$. This substantial amount of project costs would be managed by the application a systematic risk management procedure.

\section{NOMENCLATURE}

$\begin{array}{lll}\text { RF } & \text { Risk factor } & \text { no dimension } \\ \text { CR } & \text { Risk cost } & \text { IDR } \\ \text { fx } & \text { probability density function } & \% \\ \text { Fx } & \text { cumulative probability function } & \% \\ \text { Greek letters } & \\ \alpha 1 \text { and } \alpha 1 \quad \text { parameters of Beta } & \\ \mu & \text { Average } & \end{array}$

\section{ACKNOWLEDGMENT}

We would like to thank the Civil Engineering Faculty, Universitas Riau for technically facilitating this research study. We also thank the Toll Road Regulatory Agency, BPJT), PT. Jasa Marga, PT. Marga Sarana Jabar, PT. Trans Lingkar KJ, dan PT. Bintaro Serpong Damai for their contributions in the field survey.

\section{REFERENCES}

[1] S. Iqbal, R.M. Choudhry, K. Holschemacher, A. Ali, J. Tamošaitienė, Risk management in construction projects, Technol. Econ. Dev. Econ. 21, 2015, 65-78. doi:10.3846/20294913.2014.994582.

[2] A. Alhomidan, Factors Affecting Cost Overrun in Road Construction Projects in Saudi Arabia, Int. J. Civ. Environ. Eng. IJCEE-IJENS IJENS I J E N S. 2013, 1-4.

[3] T. Bjerga, T. Aven, Adaptive risk management using new risk perspectives - An example from the oil and gas industry, Reliab. Eng. Syst. Saf., 2015, 75-82. doi:10.1016/j.ress.2014.10.013.

[4] Zulfery, Analisis Investasi Pembangunan Jalan Tol Pekanbaru-Dumai, Institut Teknologi Bandung, Bandung, 2004.

[5] Anonymous, Presidential Decree No. 100/2014 concerning the Acceleration of Highway Development Programs in Sumatra Island, Indonesia, Republic of Indonesia., Jakarta, 2014.

[6] Governor, Tol Road Development Project (Pembangunan Jalan Tol Pekanbaru-Dumai di Provinsi Riau), Dinas Pemukiman dan Prasarana Wilayah Provinsi Riau, Pekanbaru, 2009.

[7] A. Sandhyavitri, M. Zulfiqar, Risk Analyses of Toll Road (Analisis Risiko Pembangunan Jalan Tol Pada Tahap Konstruksi (Studi Kasus Jalan Tol Pekanbaru-Dumai), J. Tek. Sipil. 10, 2014, 1-16.
[8] D.P.P. Riau, Financial Analysis Jalan Tol Pekanbaru-Dumai. Pekanbaru.No Title, in: Pekanbaru, 2011: pp. 1-25.

[9] I. Mahamid, Common risks affecting time overrun in road construction projects in Palestine: Contractors' perspective, Australia, J. Constr. Econ. Build. 2013.

[10] J.L. Nicolini-Llosa, Toll Road Concessions in Argentina: What Can Be Learned, Transp. Res. Rec. 1812, 2002, 10-21. doi:10.3141/181202.

[11] A. Sandhyavitri, N. Saputra, Risk Analyses of Tol Road at Pre Construction Phase (Analisis Risiko Jalan Tol tahap Pra konstruksi) Studi Kasus Jalan Tol Pekanbaru-Dumai), 2015.

[12] A.M. Khan, Risk factors in toll road life cycle analysis, Transp. A Transp. Sci. 9 (2013) 408-428. doi:10.1080/18128602.2011.587134.

[13] S. Andersen, B.A. Mostue, Risk analysis and risk management approaches applied to the petroleum industry and their applicability to IO concepts, Saf. Sci. 50, 2012, doi:10.1016/j.ssci.2011.07.016.

[14] N. Banaitiene, A. Banaitis, Risk Management in Construction Projects, Banaitiene and Banaitis, 2012. doi:10.5772/51460.

[15] P. Control, P. Management, A d v a n c e d Proj e c t M a n a g e m e n t, 2005.

[16] Raftery. J., Risk Analysis in Project Management, E \& F Spon, London, 1986.

[17] Siahaan, Hinsa, Risk Management (Manajemen Risiko), Media Komputindo, Jakarta, 2007.

[18] J.. Albahar, Systematic Risk Management Approach for Construction Projects, J. Constr. Eng. Manag. ASCE. 166, 1990, 533-546.

[19] Flanagan. R., Risk management and Construction, Wiley-Blackwell, 1993.

[20] B.L.T. et. all S., Risk management in international construction joint ventures, J. Constr. Eng. Manag. 125 (1999) 277-284.

[21] Alfian, analisa sensitivitas variabel berisiko pada pembangunan infrastruktur rencana ruas jalan tol kandis - dumai, Jurnal Aptek Vol. 3 No. 1 Januari 2010.

[22] Pertmaster, Project Risk Management Procedures, Description. (2003). papers2://publication/uuid/D5E52260-BE2B-4C6F-94718ABCB7A95B8E.

[23] P. Corporation, Guide to Using Risk Analysis and Simulation Add-In for Microsoft @ Excel, New York, USA, 2010.

[24] Project Management Institute Inc., A Guide to the Project Management Body of Knowled (PMBOK @ Guide) - Fifth Edition, I, Newtown Square, Pennsylvania 19073-3299 USA, 2013.

[25] P.L.P. Transportation, A Risk Assessment Guideline (Pedoman penilaian resiko investasi jalan tol, Pd T01-2005-B), Jakarta, 2003.

[26] Anonymous, Project Risk Management Procedures, (n.d.) 1-38. www.canrisk.com.

[27] Hasan. I., Pokok-pokok materi statistik 2 (statistik inferensif), Bumi Aksara, Jakarta, 2002.

[28] P. Corporation, Guide to Risk Analysis and Simulation Add-In for Microsoft ${ }^{\circledR}$ Excel, Ithaca, NY, USA, 2010.

[29] Richard Koch The 80/20 Principle: The Secret to Achieving More with Less, Doubleday, USA, 1998, ISBN 978038449174 7,

[30] M. Haseeb, Xinhai-Lu, A. Bibi, Maloof-ud-Dyian, W. Rabbani, Problems of Projects and Effects of Delays in the Construction Industry of Pakistan, Aust. J. Bus. Manag. Res. 1, 2011, 41-50.

[31] Anonymous, Interest During Construction for TR2A offshore transmission assets, 2011.

[32] F.R. Saragih, Indonesia Infrastructure Development, 2015. doi:10.1017/S14319276070738.

[33] A.N. Blair, L.M. Lye, W.J. Campbell, Forecasting construction cost escalation, Can. J. Civ. Eng., 1993, 602-612. doi:10.1139/193-077.

[34] Bambang Winarso, The Decoding of Traffic Signs by Motorcycle Riders in Jakarta Indonesia, International Journal of Scientific Engineering and Technology (IJASEIT), Vol.6 (2016) No. 6, ISSN: 2088-5334, 1103- 1111 .

[35] Andreea I. Niculescu, Bimlesh Wadhwa, Evan Quek, Smart City Technologies: Design and Evaluation of an Intelligent Driving Assistant for Smart Parking, International Journal of Scientific Engineering and Technology (IJASEIT), Vol.6 (2016) No. 6 ISSN: 2088-5334 1096-1102.

[36]. Fatin Ellisya Sapri, Nur Shuhada Nordin, Siti Maisarah Hasan, Wan Fairos Wan Yaacob, Syerina Azlin Md Nasir, Decision Tree Model for Non-Fatal Road Accident Injury, International Journal on Advanced Science, Engineering and Information Technology, Vol. 7 (2017) No. 1, pages: 63-70, DOI:10.18517/ijaseit.7.1.1110

[37] Sandhyavitri, A., Young, R.J, Risk management in water supply, People-Centred Approaches to Water and Environmental Sanitation: Proceedings of the 30th WEDC Conference, 2004. 
APPENDIX 1. TABLE 5.

COST ESTIMATE OF THE TOLL ROAD, RISK COSTS, AND RISK DISTRIBUTIONS IN PERT BEFORE MITIGATION.

\begin{tabular}{|c|c|c|c|c|c|c|c|c|c|}
\hline \multirow{4}{*}{ No. } & \multirow{4}{*}{ Project Activities } & \multirow{2}{*}{\begin{tabular}{|c|} 
Cost \\
$\begin{array}{c}\text { Components (IDR } \\
\text { Million) }\end{array}$ \\
\end{tabular}} & \multirow{2}{*}{ Probability (L) } & \multirow{2}{*}{ Impacts (I) } & \multirow{2}{*}{$\begin{array}{l}\text { Risks Cost (IDR } \\
\text { Million) }\end{array}$} & \multicolumn{3}{|c|}{ Distibution of Risk Costs (IDR Million) } & \multirow{2}{*}{$\begin{array}{l}\text { Results (IDR } \\
\text { Million) }\end{array}$} \\
\hline & & & & & & Minimum & Most Likely & Maximum & \\
\hline & & \begin{tabular}{|c|}
$\begin{array}{c}\text { Projection in } \\
2015\end{array}$ \\
\end{tabular} & $\begin{array}{c}\text { Research } \\
\text { Findings 2015 } \\
\end{array}$ & $\begin{array}{c}\text { Research } \\
\text { Findings 2015 } \\
\end{array}$ & {$[4]=[1] \times[2] \times[3]$} & {$[5]=[1]$} & {$[6]=([5]+[4]) / 2$} & {$[7]=[1]+[4]$} & [8] Risk Pert \\
\hline & & [1] & [2] & [3] & [4] & [5] & [6] & [7] & [8] \\
\hline 1 & 1 Land Accuisation & 780,575 & 0.643 & 0.230 & 115,439 & 780,575 & 838,295 & 896,015 & 814,526 \\
\hline 2 & Final Engineering Design (FED) & 149,906 & 0.286 & 0.258 & 11,061 & 149,906 & 155,437 & 160,967 & 151,940 \\
\hline 3 & 3 General Costs including Adm, Contract, Security, etc. & 129,928 & 0.571 & 0.170 & 12,612 & 129,928 & 136,234 & 142,540 & 134,500 \\
\hline 4 & 4 Land Clearing & 104,428 & 0.464 & 0.216 & 10,466 & 104,428 & 109,661 & 114,894 & 108,243 \\
\hline 5 & 5 Demolition & 23,257 & 0.500 & 0.276 & 3,210 & 23,257 & 24,862 & 26,467 & 25,150 \\
\hline 6 & Earthwork (Cut and fill) & $2,469,045$ & 0.607 & 0.274 & 410,647 & $2,469,045$ & $2,674,369$ & $2,879,692$ & $2,703,318$ \\
\hline 7 & 7 Excavation Structure (Foundation and Abutment) & 8,886 & 0.500 & 0.276 & 1,226 & 8,886 & 9,499 & 10,112 & 9,148 \\
\hline 8 & Drainage & 423,998 & 0.464 & 0.216 & 42,495 & 423,998 & 445,245 & 466,492 & 446,927 \\
\hline 9 & Subgrade Stabilisation & 47,936 & 0.679 & 0.307 & 9,992 & 47,936 & 52,933 & 57,929 & 52,521 \\
\hline 10 & Aggregate Base and Sub-base course & $1,224,008$ & 0.643 & 0.230 & 181,019 & $1,224,008$ & $1,314,517$ & $1,405,026$ & $1,288,330$ \\
\hline 11 & 1) Pavement (rigid and flexible) & $3,040,932$ & 0.607 & 0.274 & 505,762 & $3,040,932$ & $3,293,813$ & $3,546,694$ & $3,319,821$ \\
\hline 12 & Concrete Structures (for Bridgers. Fly overs and Pilars) & $4,290,611$ & 0.611 & 0.449 & $1,177,082$ & $4,290,611$ & $4,879,151$ & $5,467,692$ & $5,000,948$ \\
\hline 13 & 3 Structural Steel Works & 5,809 & 0.420 & 0.620 & 1,513 & 5,809 & 6,566 & 7,322 & 6,188 \\
\hline 14 & Finishing (offices, traffic signals and toll way facilities) & 673,086 & 0.643 & 0.230 & 99,543 & 673,086 & 722,857 & 772,628 & 730,945 \\
\hline 15 & 5 Lighting traffic lights and electrical work & 66,945 & 0.357 & 0.252 & 6,023 & 66,945 & 69,956 & 72,968 & 71,426 \\
\hline 16 & Construction for Toll Plaza & 57,514 & 0.679 & 0.307 & 11,989 & 57,514 & 63,508 & 69,502 & 63,242 \\
\hline 17 & 7 Diversion and protection of existing utilities (traffic management) & 122,758 & 0.464 & 0.216 & 12,303 & 122,758 & 128,909 & 135,061 & 123,785 \\
\hline 18 & TOL equipment (trucks, excavators, and transportation mobliles) & 194,860 & 0.643 & 0.230 & 28,818 & 194,860 & 209,269 & 223,678 & 206,252 \\
\hline 19 & $\begin{array}{l}\text { Works toll facilities (rail guards, pit stop, rest areas and } \\
\text { communication facilities) }\end{array}$ & 29,473 & 0.679 & 0.307 & 6,144 & 29,473 & 32,545 & 35,617 & 32,317 \\
\hline 20 & Supervision & 220,842 & 0.464 & 0.216 & 22,134 & 220,842 & 231,909 & 242,975 & 231,941 \\
\hline 21 & $\begin{array}{l}\text { Overhead for copping office operation and maintenance during } \\
\text { project construction }\end{array}$ & 336,747 & 0.464 & 0.216 & 33,750 & 336,747 & 353,622 & 370,497 & 355,103 \\
\hline 22 & Financial Cost during project implementation. & 160,811 & 0.286 & 0.258 & 11,866 & 160,811 & 166,744 & 172,677 & 166,896 \\
\hline 23 & Interest During Costruction (IDC) & $2,451,071$ & 0.607 & 0.274 & 407,657 & $2,451,071$ & $2,654,899$ & $2,858,728$ & $2,668,108$ \\
\hline 24 & Contingency required for accommodating financial risks & 659,278 & 0.643 & 0.230 & 97,501 & 659,278 & 708,029 & 756,779 & 706,157 \\
\hline 25 & 5 VAT $10 \%$ & $1,796,225$ & & & & $1,796,225$ & $1,796,225$ & $1,796,225$ & $1,796,225$ \\
\hline 26 & Cost of excalation from 2009-2011 & $2,314,496$ & 0.347 & 0.249 & 199,979 & $2,314,496$ & $2,414,486$ & $2,514,475$ & $2,413,488$ \\
\hline & TOTAL & $21,783,424$ & & & $3,420,229$ & & & & $23,627,446$ \\
\hline
\end{tabular}


APPENDIX 2.TABLE 6.

COST ESTIMATE OF THE TOLL ROAD, RISK COSTS, AND RISK DISTRIBUTIONS IN PERT AFTER MITIGATION

\begin{tabular}{|c|c|c|c|c|c|c|c|c|c|}
\hline \multirow{4}{*}{ No. } & \multirow{4}{*}{ Project Activities } & \multirow{3}{*}{\begin{tabular}{|c|} 
Cost \\
Components (IDR \\
Million) \\
$\begin{array}{c}\text { Projection in } \\
2015\end{array}$ \\
\end{tabular}} & \multirow{2}{*}{ Probability (L) } & \multirow{2}{*}{ Impacts (I) } & \multirow{2}{*}{$\begin{array}{l}\text { Risks Cost (IDR } \\
\text { Million) }\end{array}$} & \multicolumn{3}{|c|}{ Distibution of Risk Costs (IDR Million) } & \multirow{2}{*}{$\begin{array}{l}\text { Results (IDR } \\
\text { Million) }\end{array}$} \\
\hline & & & & & & Minimum & Most Likely & Maximum & \\
\hline & & & $\begin{array}{c}\text { Research } \\
\text { Findings 2015 }\end{array}$ & \begin{tabular}{c|} 
Research \\
Findings 2015 \\
\end{tabular} & {$[4]=[1] \times[2] \times[3]$} & {$[5]=[1]-[4] / 2$} & {$[6]=[1]$} & {$[7]=[1]+[4] / 2$} & [8] Risk Pert \\
\hline & & [1] & [2] & [3] & [4] & [5] & [6] & [7] & [8] \\
\hline 1 & Land Accuisation & 780,575 & 0.643 & 0.230 & 115,439 & 722,856 & 780,575 & 838,295 & 801,183 \\
\hline 2 & Final Engineering Design (FED) & 149,906 & 0.286 & 0.258 & 11,061 & 149,906 & 155,437 & 160,967 & 156,104 \\
\hline 3 & General Costs including Adm, Contract, Security, etc. & 129,928 & 0.571 & 0.170 & 12,612 & 129,928 & 136,234 & 142,540 & 139,476 \\
\hline 4 & Land Clearing & 104,428 & 0.464 & 0.216 & 10,466 & 104,428 & 109,661 & 114,894 & 112,120 \\
\hline 5 & Demolition & 23,257 & 0.500 & 0.276 & 3,210 & 23,257 & 24,862 & 26,467 & 24,748 \\
\hline 6 & Earthwork (Cut and fill) & $2,469,045$ & 0.607 & 0.274 & 410,647 & $2,263,722$ & $2,469,045$ & $2,674,369$ & $2,536,880$ \\
\hline 7 & Excavation Structure (Foundation and Abutment) & 8,886 & 0.500 & 0.276 & 1,226 & 8,886 & 9,499 & 10,112 & 9,833 \\
\hline 8 & Drainage & 423,998 & 0.464 & 0.216 & 42,495 & 423,998 & 445,245 & 466,492 & 460,153 \\
\hline 9 & Subgrade Stabilisation & 47,936 & 0.679 & 0.307 & 9,992 & 47,936 & 52,933 & 57,929 & 53,434 \\
\hline 10 & Aggregate Base and Sub-base course & $1,224,008$ & 0.643 & 0.230 & 181,019 & $1,133,499$ & $1,224,008$ & $1,314,517$ & $1,190,588$ \\
\hline 11 & Pavement (rigid and flexible) & $3,040,932$ & 0.607 & 0.274 & 505,762 & $2,788,051$ & $3,040,932$ & $3,293,813$ & $3,090,488$ \\
\hline 12 & Concrete Structures (for Bridgers. Fly overs and Pilars) & $4,290,611$ & 0.611 & 0.449 & $1,177,082$ & $3,702,070$ & $4,290,611$ & $4,879,151$ & $4,542,465$ \\
\hline 13 & Structural Steel Works & 5,809 & 0.420 & 0.620 & 1,513 & 5,809 & 6,566 & 7,322 & 5,996 \\
\hline 14 & Finishing (offices, traffic signals and toll way facilities) & 673,086 & 0.643 & 0.230 & 99,543 & 673,086 & 722,857 & 772,628 & 727,010 \\
\hline 15 & Lighting traffic lights and electrical work & 66,945 & 0.357 & 0.252 & 6,023 & 66,945 & 69,956 & 72,968 & 69,185 \\
\hline 16 & Construction for Toll Plaza & 57,514 & 0.679 & 0.307 & 11,989 & 57,514 & 63,508 & 69,502 & 61,841 \\
\hline 17 & Diversion and protection of existing utilities (traffic management) & 122,758 & 0.464 & 0.216 & 12,303 & 122,758 & 128,909 & 135,061 & 129,565 \\
\hline 18 & TOL equipment (trucks, excavators, and transportation mobliles) & 194,860 & 0.643 & 0.230 & 28,818 & 194,860 & 209,269 & 223,678 & 216,376 \\
\hline 19 & $\begin{array}{l}\text { Works toll facilities (rail guards, pit stop, rest areas and } \\
\text { communication facilities) }\end{array}$ & 29,473 & 0.679 & 0.307 & 6,144 & 29,473 & 32,545 & 35,617 & 32,283 \\
\hline 20 & Supervision & 220,842 & 0.464 & 0.216 & 22,134 & 220,842 & 231,909 & 242,975 & 230,434 \\
\hline 21 & $\begin{array}{l}\text { Overhead for copping office operation and maintenance during } \\
\text { project construction }\end{array}$ & 336,747 & 0.464 & 0.216 & 33,750 & 336,747 & 353,622 & 370,497 & 353,446 \\
\hline 22 & Financial Cost during project implementation. & 160,811 & 0.286 & 0.258 & 11,866 & 160,811 & 166,744 & 172,677 & 165,543 \\
\hline 23 & Interest During Costruction (IDC) & $2,451,071$ & 0.607 & 0.274 & 407,657 & $2,247,242$ & $2,451,071$ & $2,654,899$ & 2,326,601 \\
\hline 24 & Contingency required for accommodating financial risks & 659,278 & 0.643 & 0.230 & 97,501 & 659,278 & 708,029 & 756,779 & 742,855 \\
\hline 25 & VAT $10 \%$ & $1,796,225$ & & & & $1,796,225$ & $1,796,225$ & $1,796,225$ & $1,796,225$ \\
\hline 26 & Cost of excalation from 2009-2011 & $2,314,496$ & 0.347 & 0.249 & 199,979 & $2,214,506$ & $2,314,496$ & $2,414,486$ & $2,332,219$ \\
\hline & TOTAL & $21,783,424$ & & & $3,420,229$ & & & & $22,307,051$ \\
\hline
\end{tabular}

